\title{
INULIN AND LENTIL FLOUR AS FAT REPLACERS IN MEAT-VEGETABLE PÂTÉ - A MIXTURE DESIGN APPROACH
}

\author{
Maria Momchilova'; Dilyana Gradinarska²; Todorka Petrova'; Gabor Zsivanovits'; Ivan \\ Bakalov'; Nikolay Penov ${ }^{3}$, Dinko Yordanov ${ }^{2 *}$ \\ ${ }^{1}$ Division of Food Technology, Food Research and Development Institute, Agricultural Academy of Bulgaria, \\ 154 Vasil Aprilov Blvd., Plovdiv 4003, Bulgaria \\ ${ }^{2}$ Department of Meat and Fish Technology, University of Food Technologies, \\ 26 Maritza Blvd., Plovdiv 4002, Bulgaria. \\ ${ }^{3}$ Department of Food Preservation and Refrigeration Technology, University of Food Technologies, \\ 26 Maritza Blvd., Plovdiv 4002, Bulgaria. \\ *d_yordanov@uft-plovdiv.bg
}

https://doi.org/10.34302/cptjfst/2019.11.3.1

Article history:
Received:
9 September 2
Accepted:
20 February 201
Keywords:
Emulsion Stability;
Pâté;
Fat Replacer;
Texture.

Texture.

\begin{abstract}
In the present work, the possibilities of using inulin gel and/or lentil flour as fat replacers in recipes for canned meat products were investigated. Different inulin gel and/or lentil flour concentrations were applied in canned poultry meat pâté samples. The influence of functional replacers on the emulsion stability, texture, water content, and organoleptic parameters were studied. Significant differences were found as a result of the replacement or reduction of fat, the type and quantity of functional ingredients (inulin gel and/or lentil flour), $(\mathrm{P}<0.05)$. A direct relationship was observed between the hardness and quantity of lentil flour and inulin gel. The hardest $(\mathrm{P}<0.05)$ samples were obtained with the highest lentil flour concentration as fat content substitute. To sum up, the substitution of half of the fat with inulin and lentil flour in the formulations of the sterilized meat pâtés can be used to improve the texture and emulsification, nutrition value and health benefits of the product.
\end{abstract}

\section{Introduction}

Meat pâtés in hermetically sealed cans are ubiquitous meat products that are consumed by a wide consumer segment. However, they have a fat content of around or above $30 \%$, which has a negative impact on their health quality (Decker and Park Y., 2010; Felisberto et al., 2015; Hygreeva et al., 2014; Lorenzo et al., 2014; Oostindjer et al., 2014). This is the reason for the growing interest in the development of healthier products with an optimized concentration of functional ingredients. Nowadays, there is a widespread tendency towards the production of foods with reduced fat content, not just meatbased foods but also products in the entire food industry (Olmedilla-Alonso et al., 2013). However, fat content reduction in meat emulsions such as pâtés is often accompanied by loss of fat and water content during the thermal process (Alvarez et al., 2007). On the other hand, the formulation of a stable meat "emulsion" has been an area of interest for scientific research for many years (Acton and Dick, 1984; Gordon and Barbut, 1991; Lee and Carroll, 1981; Smith, 1988), and is considered a factor of paramount importance for obtaining a product with optimal technological and quality parameters (Bertram et al., 2000; Bertram et al., 2002; Bertram et al., 2003; Bertram et al., 2004; Di Luca et al., 2011). Dietary fiber has the 
ability to form a stable gel structure, retain fat and water (Fernández-Ginés et al., 2005), and improve texture and yield (Tokusoglu and Ünal, 2003). At the same time, however, researchers report that fat replacement with vegetable fiber may lead to a reduction in organoleptic quality because the product consistency can become less dry, hard, friable or soft (Berry and Leddy 1984; Keeton, 1994). Inulin has been successfully used in different food products for fat substitution, as energy content reducer, and improver of the structure, viscosity, emulsion and water holding parameters of food products (Boeckner et al., 2001). It is also considered a functional ingredient that carries a number of health benefits. In turn, legumes, lentils in particular, are regarded as a good source of protein, slow-release carbohydrates, dietary fiber, minerals and vitamins (Iqbal et al., 2006; Antipova and Mishenko, 2016).

The purpose of this study was to investigate the possibility of fat content substitution with inulin and/or lentil flour in order to assess their influence on the emulsion stability, texture, sensory evaluation and water content of sterilized meat pâté using a simplex-centroid plan for the three-component mixture.

\section{Materials and methods}

\subsection{Experimental statement}

The following modified recipe was used for the production of the meat vegetable pâté: turkey meat $\left(300 \mathrm{~g} \cdot \mathrm{kg}^{-1}\right)$, poultry liver $\left(100 \mathrm{~g} \cdot \mathrm{kg}^{-1}\right)$, egg mélange (150 g. $\left.\mathrm{kg}^{-1}\right)$, leaf fat $\left(250 \mathrm{~g} \cdot \mathrm{kg}^{-1}\right)$, corn starch $\left(20\right.$ g. $\left.\mathrm{kg}^{-1}\right)$, water (150 g. $\left.\mathrm{kg}^{-1}\right)$, sodium nitrite $\left(0.05\right.$ g. $\left.\mathrm{kg}^{-1}\right)$, black pepper $\left(3 \mathrm{~g} . \mathrm{kg}^{-1}\right)$, nutmeg $\left(0.5 \mathrm{~g} \cdot \mathrm{kg}^{-1}\right)$, coriander $\left(1.5 \mathrm{~g} \cdot \mathrm{kg}^{-1}\right)$, and polyphosphates $\left(2 \mathrm{~g} \cdot \mathrm{kg}^{-1}\right)$. Ten types of samples were prepared with different concentrations of leaf fat, inulin and lentil flour according to Table 1. The formulation numbers correspond to Fig. 1.
Table 1. Experimental design of three components in meat vegetable pâté formulations

\begin{tabular}{|c|c|c|c|}
\hline \multirow{2}{*}{$\begin{array}{l}\text { Sample } \\
\text { number }\end{array}$} & \multicolumn{3}{|c|}{ Ingredient proportion } \\
\hline & $\begin{array}{l}\text { Fat } \\
\left(\mathrm{X}_{1}\right)\end{array}$ & $\begin{array}{c}\text { Inulin } \\
\left(\mathrm{X}_{2}\right)\end{array}$ & $\begin{array}{l}\text { Lentil flour } \\
\left(\mathrm{X}_{3}\right)\end{array}$ \\
\hline 1 & 1.0 & 0.0 & 0.0 \\
\hline 2 & 0.0 & 1.0 & 0.0 \\
\hline 3 & 0.0 & 0.0 & 1.0 \\
\hline 4 & 0.5 & 0.5 & 0.0 \\
\hline 5 & 0.5 & 0.0 & 0.5 \\
\hline 6 & 0.0 & 0.5 & 0.5 \\
\hline 7 & 0.33 & 0.33 & 0.33 \\
\hline 8 & 0.667 & 0.167 & 0.167 \\
\hline 9 & 0.167 & 0.667 & 0.167 \\
\hline 10 & 0.167 & 0.167 & 0.667 \\
\hline
\end{tabular}

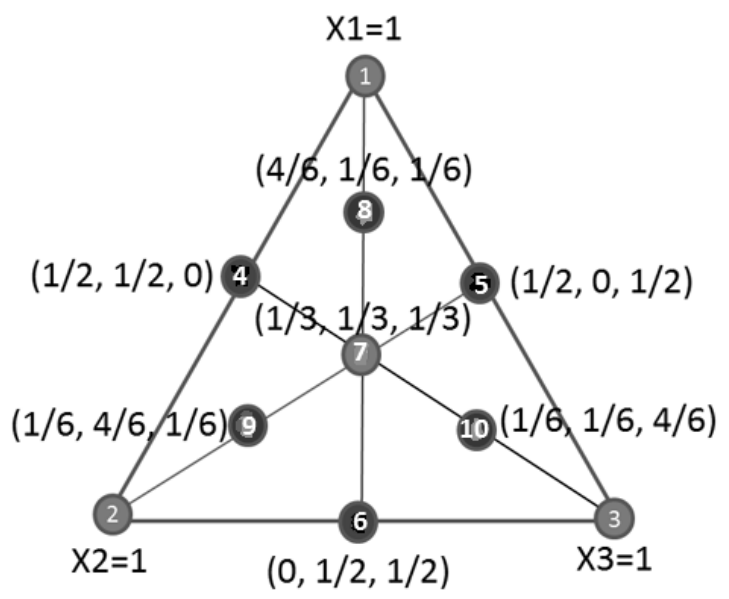

Figure 1.Ten point simplex-centroid design for the interaction of pork bacon $\left(\mathrm{X}_{1}\right)$, inulin $\left(\mathrm{X}_{2}\right)$, and lentil flour $\left(\mathrm{X}_{3}\right)$ in meat vegetable pâté formulations

The turkey meat, leaf fat (bacon) and liver were supplied by meat processing companies. Commercially purchased lentil was milled to flour and used. Inulin (Orafti®HPX) was provided by the ARTEMIS Ltd. company. The inulin was used in the form of a gel obtained by hydration in a 1:4 (w/v) ratio (Latoch et. al., 2016). For the gel preparation, the inulin water suspension was heated to $85{ }^{\circ} \mathrm{C}$ until complete dissolution and then cooled to $50{ }^{\circ} \mathrm{C}$. The two 
functional ingredients were added during processing in the cutter.

Experimental pâtés were prepared from defrosted and sliced poultry meat by grinding in a cutter (Fimar CL/5), with the addition of poultry liver. During the cutting, egg mélange, auxiliary additives and inulin and/or lentil flour were added. The cutting was continued until a fine and homogenous meat mixture was obtained. During the cutting, water was added up to $15 \%$ of the meat weight. The prepared filling mass was heated to $70{ }^{\circ} \mathrm{C}$, and then filled into 160 gram cans. The cans were closed with a sealing machine (Lanico Maschinenbau, Otto Niemsch KG, Braunschweig) and sterilized at $121^{\circ} \mathrm{C}$ for $45 \mathrm{~min}$ in an autoclave purchased from the Hydroplastform Ltd. company, Haskovo, Bulgaria.

\subsection{Analytical methods}

Texture Profile Analysis (TPA) of the finished product (Bourne, 1978) was performed using a TA-XT.Plus texture analyzer (Stable Micro Systems, Surrey, GB), cylinder in tube configuration. The cylinder was $30.37 \mathrm{~mm}$ in diameter and $51.75 \mathrm{~mm}$ in height. It was filled with about $30 \mathrm{~g}$ of sample up to a height of about $40 \mathrm{~mm}$. The samples were compressed twice at a rate of $2 \mathrm{~mm} \mathrm{~s}^{-1}$ up to $20 \mathrm{~mm}$ deformation. Relaxation time between two compressions was set to $5 \mathrm{~s}$. Hardness (Ha), adhesiveness (Ad), cohesiveness (Co) and friability ( $\mathrm{Fr}$ ) were calculated for further analysis (Bourne, 1978; Bourne, 2002; Chorbadzhiev et al., 2017).

The moisture content (MC) of the tested canned pâté samples was determined by drying at $104 \pm 1^{\circ} \mathrm{C}$ to a constant weight using a KERN MLS-A labor scale (Kern \& Sohn GmbH, Germany).

For determination of the emulsion stability, the method described by Ockerman (1985) and Zorba et al. (1993) was used.

The sensory evaluation of the samples was performed using a five-digit hedonic scale, where 5 corresponded to the highest value and 1 to the lowest value of the assessment for the given indicator. The tasting panel included a total of 10 tasters. When the cans were opened, the samples were spread on bread slices and evaluated for the following qualities: appearance, color, texture, taste, aftertaste, flavor, spreadability, and overall assessment of the perception of the products.

A three-component, simplex centroid mixture design was used. The mixture components consisted of pork bacon $\left(\mathrm{X}_{1}\right)$, inulin $\left(X_{2}\right)$ and lentil flour $\left(X_{3}\right)$. The component proportions were expressed as fractions of the mixture with a sum $\left(X_{1}+X_{2}+X_{3}\right)$ of one (Table 1). The ten points were three single components, three two-ingredient mixtures and four threeingredient mixtures (Fig. 1).

Scheffe's canonical special cubic equation for three components was fitted to data collected at each experimental point using backward stepwise multiple regression analysis as described by Cornell (2002). The canonical special cubic equation Eq. 1 was postulated:

$$
Y=\beta_{1} X_{1}+\beta_{2} X_{2}+\beta_{3} X_{3}+\beta_{12} X_{1} X_{2}+
$$
$\beta_{13} X_{1} X_{3}+\beta_{23} X_{2} X_{3}+\beta_{123} X_{1} X_{2} X_{3}$

where $\mathrm{Y}$ is a predictive dependent variable (emulsion stability, moisture, texture, and sensory evaluation); and $\beta_{1}, \beta_{2}, \beta_{3}, \beta_{12}, \beta_{13}, \beta_{23}$, and $\beta_{123}$ are the corresponding parameter estimates for each linear and cross-product term produced for the prediction models for pork bacon, inulin, and lentil flour, respectively. An analysis of variance was performed on the data and response surfaces were generated for each response using predictive models.

The terms in the canonical mixture polynomial have simple interpretations which can be found in specialized texts (Myers and Montgomery, 2002). The usual way of summarizing mixture proportions is via triangular (ternary) graphs.

\section{Results and discussions}

The experimental data obtained in the texture analysis (Table 2) demonstrated that hardness showed significant differences between the individual samples. According to some authors, hardness in meat products is associated with fat content. Ventanas et al., (2010) and Alvarez and Barbut (2013) have found that the decrease in fats in meat products 
leads to a decrease in hardness as well as in other texture parameters. In our samples, the reduction of fat and its substitution with inulin gel resulted in a decrease in hardness. This difference was proportional to the amount of inulin used. The addition of inulin gel led to values lower than those recorded in the lentil flour samples when added in the same amounts and at the same fat reduction rate of the formulation. The samples with fat, inulin gel, and lentil flour showed a gradual increase in hardness, which was most notable in the samples in which lentil flour prevailed.

The higher values found for this indicator in lentil additions were associated with the presence of large and unequally distributed clusters of flour within the thermally denatured protein matrix. Apart from the increase in the protein content due to the use of a larger amount of lentil flour, the reduced fat (Table 1) and the increased water content (Table 2), as well as the probability of formation of a greater number of intercellular bonds can be seen as the reasons for the increase in hardness. On the basis of these results and the unanimous agreement of the tasting panel members on the "too dense" consistency in these pâté samples (Table 3), it could be suggested that a direct relationship might exist between the reported values for the hardness index and the amount of lentil flour used.

Taking into account the significant differences in the adhesiveness (stickiness) of the product determined between the individual samples, the influence of the two functional additives on the characteristics of the meatvegetable pâté should be noted. The established decrease in the adhesiveness of the test samples where the fat had been completely or partially replaced with inulin gel was a direct consequence of the amount used and the moisture content of the samples.

Cohesiveness (homogeneity) is a dimensionless parameter with values ranging from 0 to 1 . The ability of cohesive products to adhere to themselves (Bourne, 2002) should be directly related to the ways in which such products form their structure capable of resisting the application of external stresses, i.e. compression or stretching. Considering the chemical composition of the additives used, it can be argued that the variations in cohesiveness in the individual samples were directly related to the higher protein content in the samples with lentil flour and the direct involvement of the lentil proteins in the building of new bonds both with meat and with non-meat proteins. High levels of stickiness are uncommon for meat products and may have a negative impact on sensory parameters. However, the very low values are also indicative of a non-typical meat product structure (Table 3 ).

Friability as a parameter has a complex character that gives a generalized idea of the structural and mechanical properties of the tested product, affecting its behavior in consumption. The reasons for the higher friability values in the samples with the addition of lentil flour and fat in close concentrations were the same, leading to the previously established solidity and cohesion (homogeneity) data for these samples. Lower scores for inulin supplements compared to lentils added were an indicator of pâté texture improvement by a gradual increase in the value of the indicator while avoiding the adverse effect of the strong modification of some other texture parameters. 
Table 2. Texture profile analysis (TPA), moisture content and emulsion stability of the meatvegetable pâtés

\begin{tabular}{|c|c|c|c|c|c|c|}
\hline \multirow{2}{*}{ 竞 } & \multicolumn{4}{|c|}{ Texture profile analysis (TPA) } & \multirow{2}{*}{$\begin{array}{c}\text { MC } \\
\text { g/100g }\end{array}$} & \multirow{2}{*}{$\begin{array}{c}\text { ES } \\
\%\end{array}$} \\
\hline & Ha, $\mathbf{N}$ & Ad, $\mathbf{N m m}$ & Co, - & Fr, $\mathbf{N}$ & & \\
\hline 1 & $61.67^{\mathrm{b}}$ & $-64.63^{b}$ & $0.20^{\mathrm{a}}$ & $12.69^{\mathrm{b}}$ & $54.81^{\mathrm{ab}}$ & $97.92^{c}$ \\
\hline 2 & $24.71^{\mathrm{a}}$ & $-12.06^{\mathrm{c}}$ & $0.25^{\mathrm{abc}}$ & $6.14^{\mathrm{a}}$ & $67.66^{\mathrm{f}}$ & $90.73^{\mathrm{a}}$ \\
\hline 3 & $127.75^{\mathrm{d}}$ & $-130.15^{\mathrm{a}}$ & $0.27^{\mathrm{cd}}$ & $34.91^{\mathrm{d}}$ & $67.66^{\mathrm{f}}$ & $100.00^{\mathrm{d}}$ \\
\hline 4 & $26.98^{\mathrm{a}}$ & $-21.61^{\mathrm{c}}$ & $0.25^{\mathrm{bcd}}$ & $6.71^{\mathrm{a}}$ & $58.62^{\text {bc }}$ & $96.37^{b}$ \\
\hline 5 & $170.68^{f}$ & $-137.23^{\mathrm{a}}$ & $0.28^{\mathrm{cd}}$ & $47.30^{\mathrm{e}}$ & $54.03^{\mathrm{a}}$ & $99.96^{\mathrm{d}}$ \\
\hline 6 & $69.33^{\mathrm{b}}$ & $-64.79^{b}$ & $0.25^{\mathrm{bcd}}$ & $17.62^{\mathrm{bc}}$ & $62.75^{\mathrm{de}}$ & $99.91^{\mathrm{d}}$ \\
\hline 7 & $63.10^{\mathrm{b}}$ & $-72.66^{\mathrm{b}}$ & $0.25^{\mathrm{abcd}}$ & $15.79^{\mathrm{bc}}$ & $59.1^{\mathrm{cd}}$ & $99.83^{d}$ \\
\hline 8 & $87.90^{\mathrm{c}}$ & $-81.22^{b}$ & $0.22^{\mathrm{ab}}$ & $19.07^{\mathrm{c}}$ & $53.53^{\mathrm{a}}$ & $99.88^{d}$ \\
\hline 9 & $23.94^{\mathrm{a}}$ & $-18.10^{c}$ & $0.23^{\mathrm{abc}}$ & $5.56^{\mathrm{a}}$ & $64.97 \mathrm{e}^{\mathrm{f}}$ & $96.48^{b}$ \\
\hline 10 & $143.75^{\mathrm{e}}$ & $-129.08^{a}$ & $0.29^{d}$ & $42.24^{\mathrm{e}}$ & $60.33^{\mathrm{cd}}$ & $99.97^{d}$ \\
\hline
\end{tabular}

The values for the respective sample are the arithmetic mean of 5 measurements for the given indicator ${ }^{a-f}$-values within the same column bearing a common superscript did not differ statistically $(P<0.05)$

The comparison of the data on the water content of meat-vegetable pâtés (Table 2) showed that the addition of the two functional additives, inulin and lentil flour, resulted in a product with higher moisture content. This became more pronounced when the fat content was lowered and fat was replaced with higher amounts of inulin or lentil flour. The reason for this was undoubtedly the high water holding capacity and hygroscopic properties of the additives, which favored the ability of the product to retain the added water. A number of other authors have also reported these properties (Felisberto et al., 2015; Kaur, et al., 2007).

To assess the influence of the functional additives (inulin and lentil flour) used on the gel forming and emulsifying capacity of the filling mass and the finished sterilized pâtés, tests were conducted to determine the resultant emulsion stability (Table 2). A statistically significant difference was found in this indicator between sample 1, which contained $100 \%$ fat, and the other samples. The results showed that the addition of lentil flour significantly improved the emulsion stability of the filling mass and the resulting products in all the samples, with values exceeding $99.00 \%$. The highest concentration of lentil flour resulted in the most stable meat emulsion: $100.00 \%$ in sample 3; however, according to the numerical expression of this optimization, it was statistically the same with all samples containing lentil flour $(\mathrm{P}>0.05)$. In contrast, the lowest value for the emulsion stability was recorded in the sample formulations where the fat was replaced only by inulin gel (sample 2). Felisberto et al. (2015) indicated the formation of a more brittle protein gel with the involvement of inulin and indicated the need for another ingredient to reduce this destabilizing effect and improve the meat emulsion stability. The advantage of the addition of lentil flour as a protein supplement in terms of meat emulsion stability is associated with its ability to participate in the formation of a stronger protein structure that favors the capturing of water molecules and fat globules (Table 2) (Gordon et al., 1992) as compared to the protein matrix formed only by inulin gel or 
inulin gel and fat. In sample 2, the absence of fat and its replacement with inulin led to water loss, resulting in visible phase separation after heat treatment. Similarly, the results of Cáceres et al., (2004) explained the decreased stability of the emulsion with the limited ability of the meat proteins to retain water in the compact structure of the inulin gel. In addition (Carballo et al., 1996), gels formed with polysaccharides lead to the formation of a more compact and stronger thermally induced protein matrix, reducing its ability to retain water and thereby increasing the loss of liquid after thermal processing.

Table 3. Sensory analyses of the meat-vegetable cans

\begin{tabular}{|c|c|c|c|c|c|c|c|c|}
\hline \multirow[b]{2}{*}{ 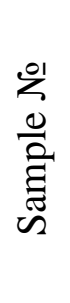 } & \multicolumn{8}{|c|}{ Parameter } \\
\hline & 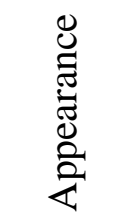 & $\frac{\overline{0}}{0}$ & 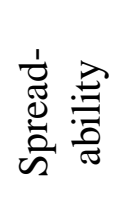 & $\begin{array}{l}\stackrel{0}{\Xi} \\
\stackrel{0}{Z}\end{array}$ & $\begin{array}{l}\overrightarrow{0} \\
\frac{0}{ \pm} \\
\frac{0}{0} \\
0 \\
0 \\
0\end{array}$ & 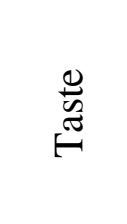 & 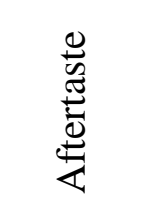 & 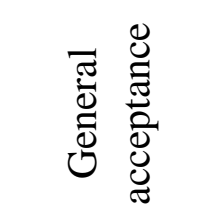 \\
\hline 1 & $4.05^{\mathrm{g}}$ & $4.35^{f}$ & $4.35^{\mathrm{e}}$ & $4.00^{\mathrm{d}}$ & $4.15^{\mathrm{e}}$ & $4.55^{\mathrm{e}}$ & $4.55^{\mathrm{f}}$ & $4.60 \pm 0.66^{\mathrm{d}}$ \\
\hline 2 & $2.70^{\text {cde }}$ & $3.40^{\mathrm{cdf}}$ & $3.75^{\mathrm{de}}$ & $3.35^{\mathrm{cd}}$ & $2.30^{\mathrm{ab}}$ & $3.60^{\mathrm{bcd}}$ & $3.70^{\text {def }}$ & $3.45 \pm 1.21^{b c}$ \\
\hline 3 & $1.25^{\mathrm{a}}$ & $1.15^{\mathrm{a}}$ & $1.55^{\mathrm{a}}$ & $2.05^{\mathrm{a}}$ & $1.70^{\mathrm{a}}$ & $2.20^{\mathrm{a}}$ & $2.25^{\mathrm{a}}$ & $1.85 \pm 0.94^{\mathrm{a}}$ \\
\hline 4 & $3.50^{\mathrm{fg}}$ & $3.75^{\mathrm{df}}$ & $4.25^{\mathrm{e}}$ & $3.75^{\mathrm{cd}}$ & $3.35^{\text {cde }}$ & $3.85^{\mathrm{cd}}$ & $4.00^{\mathrm{ef}}$ & $3.85 \pm 1.16^{\mathrm{cd}}$ \\
\hline 5 & $2.25^{\mathrm{bc}}$ & $2.45^{\mathrm{bc}}$ & $2.25^{\mathrm{ab}}$ & $2.85^{\mathrm{abc}}$ & $3.10^{\mathrm{bcd}}$ & $2.70^{\mathrm{ab}}$ & $2.45^{\mathrm{ab}}$ & $2.55 \pm 1.17^{\mathrm{ab}}$ \\
\hline 6 & $3.25^{\mathrm{ef}}$ & $3.20^{\mathrm{cd}}$ & $2.70^{\mathrm{bc}}$ & $3.05^{\mathrm{bc}}$ & $3.75^{\mathrm{cde}}$ & $2.75^{\mathrm{ab}}$ & $2.60^{\mathrm{abc}}$ & $3.15 \pm 0.91^{b c}$ \\
\hline 7 & $3.25^{\mathrm{ef}}$ & $2.90^{\mathrm{cd}}$ & $3.60^{\mathrm{de}}$ & $3.45^{\mathrm{bcd}}$ & $3.90^{\mathrm{de}}$ & $3.60^{\mathrm{bcd}}$ & $3.45^{\text {bcde }}$ & $3.65 \pm 0.67^{c}$ \\
\hline 8 & $3.25^{\mathrm{ef}}$ & $3.35^{\mathrm{cd}}$ & $3.10^{\mathrm{cd}}$ & $3.65^{\mathrm{cd}}$ & $3.85^{\text {cde }}$ & $3.10^{\mathrm{abc}}$ & $3.35^{\text {bcde }}$ & $3.40 \pm 0.99^{\mathrm{bc}}$ \\
\hline 9 & $3.25^{\mathrm{ef}}$ & $2.95^{\mathrm{cd}}$ & $4.30^{\mathrm{e}}$ & $3.40^{\mathrm{bcd}}$ & $3.20^{\mathrm{bcd}}$ & $4.15^{\mathrm{e}}$ & $3.65^{\text {cdef }}$ & $3.65 \pm 1.20^{\mathrm{c}}$ \\
\hline 10 & $3.25^{\mathrm{ef}}$ & $1.80^{\mathrm{ab}}$ & $2.20^{\mathrm{ab}}$ & $2.55^{\mathrm{ab}}$ & $2.95^{\mathrm{bc}}$ & $2.90^{\mathrm{abc}}$ & $2.75^{\text {abcd }}$ & $2.70 \pm 1.03^{\mathrm{ab}}$ \\
\hline
\end{tabular}

The values for the respective sample are the arithmetic mean of 5 measurements for the given indicator ${ }^{a-f}$-values within same column bearing a common superscript did not differ statistically $(P<0.05)$

The results of the sensory analysis for the individual indicators as well as for the general acceptance as shown in Table 3 made it possible to assert that the type and quantity of the functional additives added had a significant effect on the organoleptic characteristics of the finished canned meat samples.

A lower score for the indicator was recorded in the samples with a higher concentration of inulin that was associated with the presence of surface-migrated fat and segregated water and corresponded to the observed lower emulsifiability of these pâtés. Sample 2 demonstrated the largest amount of fluid released on the surface, and samples 1, 5 and 8, fat removal. The highest grade was given to the visual appearance of sample 1, which was statistically distinct from all other samples $(\mathrm{P}<$
$0.05)$, and the closest to it was the estimate for sample 4 , in which $50 \%$ of the fat had been replaced with inulin gel. A similar trend was also found with the organoleptic scores for the color indicator. The highest grade for this indicator was excellent for sample 1, followed by sample 4. The lowest scores were given to samples 3,5 , and 10, in which the color was assessed as uncharacteristic for this product range. Unfavorable color changes were found in the samples with the largest amount of lentil flour. The deterioration of the color characteristics was expressed as darkening of the color of the product and a less pronounced red color. The darkening was probably due to non-enzymatic reactions occurring during the subsequent sterilization regime. The data obtained 
corresponded to those from the pictures of the captured samples (not shown).

In the samples prepared with the addition of lentil flour, consistency deficiencies were also observed, with the highest deviations found in sample 3 (100\% fat replacement with lentil flour). The atypical consistency was described as "too stiff and crumbly". Here too, there was a coincidence of the established trends with those recorded in the previous analyses related to the structural and mechanical properties and, more precisely, to the established hardness, homogeneity, and friability of the product.
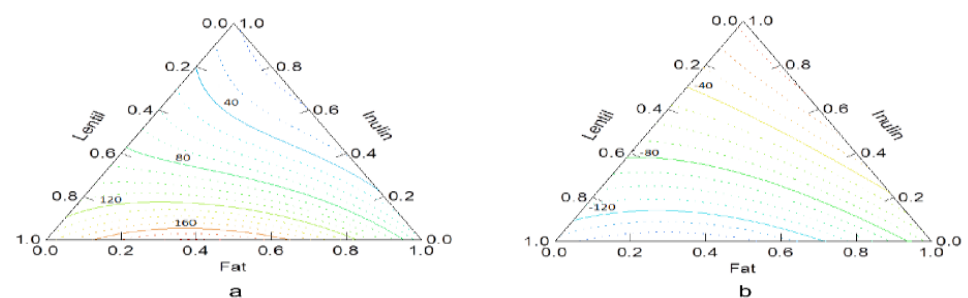

0,10
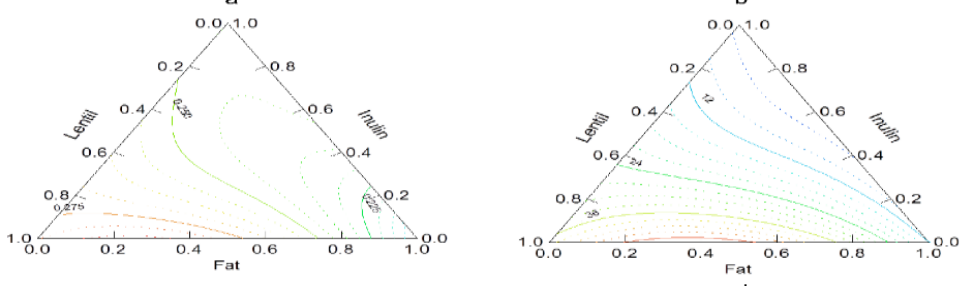

$0.0,1.0$

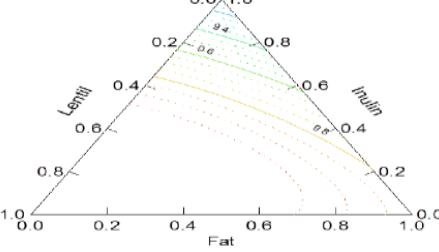

e

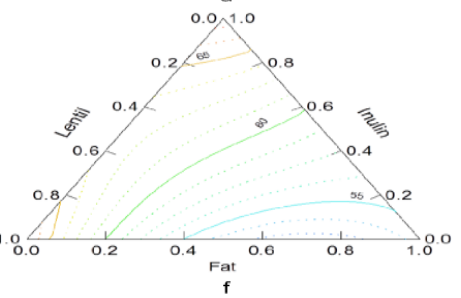

0,10
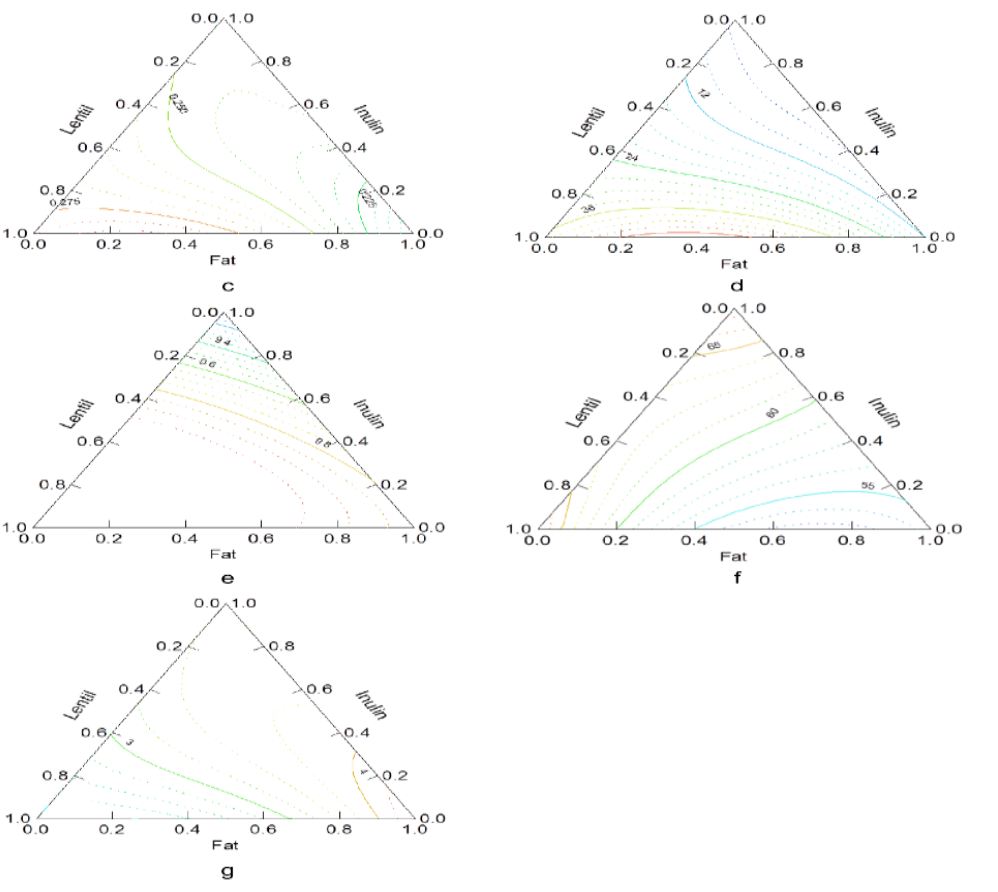
The analysis of the results obtained by the tasting panel on the taste and aroma indicators revealed differences in the pâtés studied. The testimonies were as close as possible to the expectations and perceptions of sample 1, followed by samples 4, 8, 9, and 2. The reduction in the fat amount and its replacement with inulin gel resulted in products having good taste and aroma. Similar results have also been reported for the production of boiled sausages with added inulin (Šojić et al., 2011). In low-fat samples and samples with lentil flour substitute, there was a decrease in taste and aroma intensity, which made it non-specific for the product, i.e. sterilized pâté.

The comparison of the total scores obtained from the experiment showed that the highest scores were given to samples 1 and $4(\mathrm{P}<0.05)$.

Using the simplex method and the modeling and optimization procedures related to it and after processing of the results, equations for texture (hardness, adhesiveness, homogeneity and friability), emulsion stability, moisture, and sensory evaluation were obtained as follows:

$$
\begin{aligned}
& Y_{1}(\text { hardness })=62.56 X_{1}+20.74 X_{2}+134.03 X_{3}+70.99 X_{1} X_{2}+318.22 X_{1} X_{3}+ \\
& 23.00 X_{2} X_{3}+665.80 X_{1} X_{2} X_{3}\left(R^{2}=0.97\right) \\
& Y_{2}(\text { adhesiveness })=-65.83 X_{1}-7.41 X_{2}-134.52 X_{3}+73.85 X_{1} X_{2}-170.50 X_{1} X_{3}+ \\
& 25.83 X_{2} X_{3}+46.13 X_{1} X_{2} X_{3}\left(R^{2}=0.98\right) \\
& Y_{3}(\text { homogeneity })=0.20 X_{1}+0.24 X_{2}+0.28 X_{3}+0.09 X_{1} X_{2}+0.16 X_{1} X_{3}+0.02 X_{2} X_{3}+ \\
& 0.54 X_{1} X_{2} X_{3}\left(R^{2}=0.78\right) \\
& Y_{4}(\text { friability })=12.03 X_{1}+5.08 X_{2}+37.55 X_{3}-14.27 X_{1} X_{2}+97.93 X_{1} X_{3}-8.44 X_{2} X_{3}- \\
& 217.25 X_{1} X_{2} X_{3}\left(R^{2}=0.95\right) \\
& Y_{5}(\text { emulsion stability })=98.16 X_{1}+90.70 X_{2}+99.76 X_{3}+8.62 X_{1} X_{2}+4.00 X_{1} X_{3}+ \\
& 17.64 X_{2} X_{3}+5.05 X_{1} X_{2} X_{3}\left(R^{2}=0.98\right) \\
& Y_{6}(\text { moisture })=54.32 X_{1}+68.33 X_{2}+67.48 X_{3}-10.10 X_{1} X_{2}-30.16 X_{1} X_{3}-18.66 X_{2} X_{3}+ \\
& 61.42 X_{1} X_{2} X_{3}\left(R^{2}=0.97\right) \\
& Y_{7}(\text { sensory evaluation })=4.50 X_{1}+3.47 X_{2}+1.88 X_{3}-0.85 X_{1} X_{2}-2.84 X_{1} X_{3}+ \\
& 2.09 X_{2} X_{3}+40.69 X_{1} X_{2} X_{3}\left(R^{2}=0.97\right)
\end{aligned}
$$

The resulting equations describe with high accuracy the change in the contents of the dependent variable $(\mathrm{R} 2>0.9)$, except for the equation for homogeneity, where it was 0.78 . The two-dimensional contour plots are shown in Fig. 2.

\section{Conclusions}

On the basis of the analysis, a conclusion can be drawn that the experimentally obtained data were objective evidence of the effect of the functional additives used on the texture, emulsion stability, water content and sensory evaluation of the sterilized meat-vegetable pâtés. The main reason for the differences established between the tested samples was the type and amount of the functional additives incorporated (inulin gel and lentil flour). In the inulin gel containing samples, hardness and homogeneity were less pronounced and depended on the amount of inulin used. More undesirable texture characteristics were found in the samples with higher amounts of lentil flour added and reduced fat content, which corresponded very well to the results of the sensory analysis. The low scores given by the tasting panel to these samples were a direct consequence of the deviations in texture and consistency that were not typical of the product range. However, the incorporation of lentil flour into the filling mass resulted in a better emulsion stability, which meant that meat-based vegetable pâtés having the necessary characteristics for this product range could be manufactured.

\section{References}

Acton, J.C. \& Dick, R.L. (1984). Protein-protein interaction in processed meats. Proceeding 
of 37th Reciprocal Meat Conference.Texas Tech University. Texas, pp 36-42.

Alvarez, D. \& Barbut, S. (2013) Effect of inulin, $\beta$-glucan and their mixtures on emulsion stability, color and textural parameters of cooked meat batters. Meat Science, 94, 320327.

Alvarez, D., Castillo, M., Payne, F.A., Garrido, M.D., Bañón, S., Xiong, Y.L. (2007). Prediction of meat emulsion stability using reflection photometry. Journal of Food Engineering, 82(3), 310-315.

Antipova, L.V., Mishenko, A.A. (2016). The development of meat pate increased the food and biological values with determinate grains lentils. Vestnik VSUET, 4, 115-120. (in Russian).

Berry, B.W. \& Leddy, K.F. (1984. Effects of fat level and cooking method on sensory and textural properties of ground beef patties. Journal of Food Science, 49(3), 870-875.

Bertram, H.C., Karlsson, A.H., Andersen, H.J. (2003). The significance of cooling rate on water dynamics in porcine muscle from heterozygote carriers and non-carriers of the halothane gene - a low-field NMR relaxation study. Meat Science, 65(4), 12811291.

Bertram, H.C., Petersen, J.S., Andersen, H.J. (2000). Relationship between $\mathrm{RN}$-genotype and drip loss in meat from Danish pigs. Meat Science, 56(1), 49-55.

Bertram, H.C., Purslow, P.P., Andersen, H.J. (2002). Relationship between Meat Structure, Water Mobility, and Distribution: A Low-Field Nuclear Magnetic Resonance Study. Journal of Agricultural and Food Chemistry, 2002; 50(4), 824-829.

Bertram, H.C., Schäfer, A., Rosenvold, K., Andersen, H.J. (2004). Physical changes of significance for early post mortem water distribution in porcine M. longissimus. Meat Science, 2004; 66(4), 915-924.

Boeckner, L.S., Schnepf, M.I., Tungland, B.C. (2001). Inulin: a review of nutritional and health implications. Advances in Food Nutrition Research. 43, 1-63.
Bourne, M. (2002). Food texture and viscosity: concept and measurement (2nd ed.). New York: Academic Press.

Bourne, M.C. (1978) Texture profile analysis. Food Technology, 32, 62-66.

Cáceres, E., Garcıa, M.L., Toro, J., Selgas, M.D. (2004). The effect of fructooligosaccharides on the sensory characteristics of cooked sausages. Meat Science, 68(1), 87-96.

Carballo, J., Fernandez, P., Barreto, G., Solas, M.T., Colmenero, F.J. (1996). Morphology and texture of bologna sausage as related to content of fat, starch and egg white. Journal of Food Science; 61(3), 652-665.

Chorbadzhiev, P., Zsivanovits, G., Gradinarska, D., Danov, K., Valkova-Jorgova, K. (2017). Improvement Of Texture Profile Attributes Of Cooked Sausage Type "Krenvirsh", Bulgarian Journal of Agricultural Science, 23 (2), 338-347.

Cornell, J. (2002). Experiments with Mixtures: Designs, Models, and the Analysis of Mixture Data. 3rd edition. Wiley: New York.

Decker, E. \& Park, Y. (2010). Healthier meat products as functional foods. Meat Science, $86,49-55$.

Di Luca, A., Mullen, A.M., Elia, G., Davey, G., Hamill, R.M. (2011). Centrifugal drip is an accessible source for protein indicators of pork aging and water-holding capacity. Meat science, 88(2), 261-270.

Felisberto, M.H.F., Galvão, M.T.E.L., Picone, C.S.F., Cunha, R.L., Pollonio, M.A.R. (2015). Effect of prebiotic ingredients on the rheological properties and microstructure of reduced-sodium and low-fat meat emulsions. LWT-Food Science and Technology, 60(1), 148-155.

Fernández-Ginés, J.M., Fernández-López, J., Sayas-Barberá, E., Pérez-Alvarez, J. (2005). Meat products as functional foods: A review. Journal of Food Science, 70(2), 3743.

Gordon, A., Barbut, S., Schmidt, G. (1992). Mechanisms of meat batter stabilization: a review. Critical Review in Food Science and Nutrition, 32(4), 299-332. 
Gordon, A. \& Barbut, S. (1991). Raw meat batter stabilization: Morphological study of the role of interfacial protein film. Canadian Institute of Food Science and Technology Journal, 1991; 24(3-4), 136-142.

Hygreeva, D., Pandey, M., Radhakrishna, K. (2014). Potential applications of plant based derivatives as fat replacers, antioxidants and antimicrobials in fresh and processed meat products. Meat Science, 98(1), 47-57.

Iqbal, A., Khalil, I.A., Ateeq, N., Khan, MS. (2006). Nutritional quality of important food legumes. Food Chemistry, 97(2), 331-335.

Kaur, M., Singh, N., Sandhu, K.S. (2007). Preparation and characterization of protein isolates from different lentil (Lens culinaris) cultivars. Journal of Food Science and Technology-Mysore, 44(3), 327-329.

Keeton, J.T. (1994). Low-fat meat productstechnological problems with processing. Meat Science, 36(1-2), 261-276.

Latoch, A., Glibowski, P., Libera, J. (2016). The effect of replacing pork fat of inulin on the physicochemical and sensory quality of guinea fowl pâté. Acta Scientiarum Polonorum Technologia Alimentaria, 15(3), 311-320.

Lee, C.M. \& Carroll, R.J. (1981). Study of the Structure of Meat Emulsions and Its Relationship to Thermal Stability. Journal of Food Science, 46(6), 1789-1793.

Lorenzo, J., Pâtéiro, M., Fontán, M., Carballo, J. (2014). Effect of fat content on physical, microbial, lipid and protein changes during chill storage of foal liver pâté. Food Chemistry, 155, 57-63.

Myers, R. \& Montgomery, D. (2002). Response surface methodology: Process and product optimization using Designed Experiments. 2nd ed. New York: John Wiley \& Sons.

Ockerman, H.W. (1985). Quality control of post-mortem muscle tissue. Dept. of Animal Science, Ohio State University.

Olmedilla-Alonso, B., Jiménez-Colmenero, F., Sánchez-Muniz, F.J. (2013). Development and assessment of healthy properties of meat and meat products designed as functional foods. Meat Science, 95(4), 919-930.
Oostindjer, M., Alexander, J., Amdam, G.V., Andersen, G., Bryan, N.S., Chen, D., et al. (2014). The role of red and processed meat in colorectal cancer development: a perspective. Meat science, 97(4), 583-596.

Smith, D.M. (1988). Meat proteins-functionalproperties in comminuted meat-products. Food Technology, 42(4), 116-121.

Šojić, B.V., Petrović, L.S., Pešović, B.M., Tomović, V.M., Jokanović, M.R., Džinić, N.R., et al. (2011). The influence of inulin addition on the physico-chemical and sensory characteristics of reduced-fat cooked sausages. Acta Periodica Technologica, 42, 157-164.

Tokusoglu, Ö. \& Ünal, M.K. (2003). Fat replacers in meat products. Pakistan Journal of Nutrition, 2(3), 196-203.

Ventanas, S., Puolanne, E., Tuorila, H. (2010). Temporal changes of flavour and texture in cooked bologna type sausages as affected by fat and salt content. Meat Science, 85(3), 410-419.

Zorba, O., Gokalp, H.Y., Yetim, H., Ockerman, H.W. (1993). Salt, phosphate and oil temperature effects on emulsion capacity of fresh or frozen meat and sheep tail fat. Journal of Food Science, 58(3), 492-496.

\section{Acknowledgment}

The authors thank the ARTEMIS Ltd. Company, Sofia, Bulgaria, for providing the inulin. 